\title{
Research Infrastructure
}

National Cancer Institute

\section{Source}

National Cancer Institute. Research Infrastructure. NCI Thesaurus. Code C19158.

Refers to the physical structures needed to conduct research as well as the basic services needed for support, eg shipping and receiving services, waste management, and utilities. 